\title{
Gender and Return in the Kimbanguist Church of Portugal
}

\author{
Ramon Sarró \\ Institute of Social Sciences, University of Lisbon, \\ 1600-189 Lisbon, Portugal \\ ramonsarro@gmail.com \\ Joana Santos \\ Institute of Social Sciences, University of Lisbon, \\ 1600-189 Lisbon, Portugal \\ joaninhas.joana@gmail.com
}

\begin{abstract}
This article analyzes some events related to the Kimbanguist church that have taken place in Portugal and in the Democratic Republic of Congo. It unearths a connection between an increasing feminization of practices and narratives within this church and the emergence of an ideology of return to Africa linked both to eschatological beliefs and to notions of 'mission,' 'example,' and 'success.' The article shows the advantage of a multi-sited fieldwork in the study of transnational religion, as well as the changing nature of religious institutions in today's world, in which socio-political dynamics in the migrants' new settings both affect and are affected by what happens in the headquarters of their religious institution.
\end{abstract}

\section{Keywords}

Kimbanguism, gender, migration, Africa, Portugal, Christian mission, transnational religion

\section{The Second Burial of Mama Mwilu}

In October 2009, after a long negotiation between the Kimbanguist church, the Congolese state and local traditional authorities in the Kikongospeaking region of Lower Congo, Mama Mwilu's body was exhumed and 
solemnly transferred from the village where she had been buried in 1959 to the holy city of N'Kamba-New Jerusalem in Lower Congo. There she was finally reunited with her husband and their three sons, all buried at the mausoleum. It was a moment of post-mortem family reunion, very solemnly experienced by the thousands of pilgrims from all over the world who went to N'Kamba-New Jerusalem to witness the reburial and pray. One of us (Ramon Sarró) was invited to be there too, and was particularly impressed, not only by the deep emotions of thousands of believers, but by the words of one pastor in particular who, in the meeting's sermon the following day very solemnly proclaimed: "this is the moment." The 'moment' was the day Mama Mwilu was being transferred to N'KambaNew Jerusalem (a long awaited moment) and reunited with her husband. In Christian theological terms, this is called kairos, the exceptional time that breaks into the continuity of chronos, the ordinary time, and implies a different outlook on the world henceforth.

Mama Mwilu was the wife of Simon Kimbangu (1887-1951), the spiritual leader who gave birth to Kimbanguism in 1921. Kimbangu is understood by Kimbanguists as the Paraclete, the Holy Ghost promised by Jesus to live among people in human presence forever. ${ }^{1}$ Perceived as an anticolonial leader, the prophetic leader Simon Kimbangu was imprisoned by the Belgians in 1921 and stayed in prison till his death in 1951. Despite the incarceration, suffering and death of the founder, the Kimbanguist movement subsisted clandestinely, thanks to the tenacity of his wife Mwilu and later to the efforts of their three sons too. In 1959, just one year before Independence, the Kimbanguist church was recognized by the Belgians. During the 1960s and 1970s, under the tutelage of Simon Kimbangu and Mwilu's last son (Joseph Diangienda Kuntima), Kimbanguism became one of the major official Christian denominations of independent Congo (or, as the country would later be called, Zaire). Already in 1960 the founder's body was transferred from Lubumbashi to his natal village of N'kamba, where the above-mentioned mausoleum was built. The role of Diangienda and his two brothers has been consistently analyzed in the recent literature on Kimbanguism. ${ }^{2}$ Yet, it is only very recently that scholars have started to

\footnotetext{
1) Leon N. Kayongo, "Kimbanguism: Its Present Christian Doctrine and the Problems Raised by It," Exchange 34/3 (2005), 135-155.

2) Anne Mélice, "Le Kimbanguisme et le Pouvoir en RDC: Entre Apolitisme et Conception Théologico-politique," Civilisations LVIII/2 (2009), 59-79; Anne Mélice, "La Désobéissance Civile des Kimbanguistes et la Violence Coloniale au Congo Belge," Les Temps Modernes,
} 
pay attention to the female figure of Mama Mwilu, ${ }^{3}$ who is acquiring a bigger and bigger presence in the church's narratives, theology and material culture. Her increasing presence is giving a visible and explicit feminine element to a church that had until recently been mostly associated to the figure of Simon Kimbangu. Today, and especially since the fiftieth anniversary of her death in April 2009 and of her exhumation in October 2009, images of Mama Mwilu abound in all parishes and households we have visited in Lisbon, France, the Netherlands and the Democratic Republic of Congo. On the walls of many of people, the image of Simon Kimbangu is no longer on his own, as used to be the case until a few years ago.

As a Kimbanguist woman put it to us, Mama Mwilu is considered as a 'role model' for all Kimbanguist women in issues related to conduct and lifestyle. Mama Mwilu's actions during her life, especially her role and commitment in maintaining and expanding her husband's spiritual work and message, represent for both men and women a demonstration of support and of complement to Simon Kimbangu's actions. While it would be tempting to interpret the notion of 'support' as indicating subordination to the role of men, women in fact see their role as being equally, if not more important than that of men. The increasing importance of Mama Mwilu in Kimbanguist theology and everyday culture makes men also take a high view on the feminine side of their religion. ${ }^{4}$ Women we interviewed in Lisbon expressed their belonging to the church not only in terms of

658/659 (2010), 218-250; Aurélien M. Gampiot, Les Kimbanguistes en France: Expression Messianique d'une Église Afro-Chrétienne en Contexte Migratoire (Paris: L'Harmattan, 2010); David Garbin, "Symbolic Geographies of the Sacred: Diasporic Territorialisation and Charismatic Power in a Transnational Congolese Prophetic Church," in: G. Hüwelmeier \& K. Krause (eds.), Traveling Spirits: Migrants, Markets and Mobilities (London: Routledge, 2009), 145-164.

3) Joana Santos, "Religião no Feminino: Experiências da 'Mulher Kimbanguista' em Portugal," (MA Thesis. Lisbon: ISCTE, 2010).

4) Like in many other religious cultures-and certainly in Subsaharan contexts-women's religiosity can sometimes go out of male control. In many Kimbanguist churches worldwide women at times become possessed by the spirit of Kimbangu, or of one of his three sons. These spirit possessions are not accepted by mainline theology, and tensions occur between men and women when they are experienced or witnessed. David Garbin has explored this phenomenon in Great Britain. See David Garbin, "Embodied Spirit(s) and Charismatic Power among Congolese Migrants in London," in: A. Dawson (ed.), Summoning the Spirits: Possession and Invocation in Contemporary Religion (New York: I.B. Tauris, 2010), 40-57. We have encountered trance-like situations in Lisbon, but so far men manage to control and interpret these trances along accepted theological lines. 
'support' but in much more creative terms too. One of them recalled an African saying according to which "women do not build a village," and immediately and proudly stated that "Kimbanguist women have demonstrated otherwise: a woman can also build, and this is why she, Mama Mwilu, was able to take care of this church." Indeed it seems as though it is the feminization of the church that is bringing the believers together in diasporic times (also in times of an internal crisis of the church, divided in two wings since 2002). It is tempting to analyze this in the light of the matriliniality of the Bakongo and of the structural tensions typical of matrilineal societies in Central Africa, which A.I. Richards famously referred to as "the matrilineal puzzle." The tension between matrilinealily and patrilinality in the Kimbanguist church and its role in the crisis the church endures since 2002 has been analyzed by Ramon Sarró, Ruy Blanes and Fátima Viegas. ${ }^{6}$

Originally, the exhumation of Mama Mwilu was planned to coincide with the jubilee of her death in April 2009. However, administrative delays forced the church to put off the ceremony till 12 October, thus coinciding with the anniversary of Kimbangu's death on 12 October 1951. In any case, this has not been the only event commemorated in the last years, particularly dense in Kimbanguist and Congolese remembering. Together with Mama Mwilu's death, the remembrance of the official recognition of the church by the Belgians in December 1959 has been another cherished memory, re-enacted during its fiftieth anniversary in 2009. Together with these events, the recent jubilee of Congolese independence, celebrated in June 2010, has also been a highly symbolic moment in which the person and message of Kimbangu has been vividly remembered in Africa and its diasporas - not only by Kimbanguists but by many Congolese and other Africans.

The 'Triumphal Entry of Mama Mwilu in N'kamba-New Jerusalem,' as the second burial is officially called, has been experienced by Kimbanguists as a marking event that should indicate the beginning of a new era, closer to the messianic times announced by Simon Kimbangu, to which we will return at the end of this article.

5) Audrey I. Richards, "Some Types of Family Structure amongst the Central Bantu," in: Alfred R. Radcliffe-Brown \& Daryll Forde (eds.), African Systems of Kinship (London: Oxford University Press, 1950), 207-251.

6) Ramon Sarró, Ruy Blanes \& Fátima Viegas, "La Guerre dans la Paix: Ethnicité et Angolanité dans l'Église Kimbanguiste de Luanda," Politique africaine 110 (2008), 84-101. 
Following the invitation of the pastor in N'kamba-New Jerusalem in 2009 to take the day Mama Mwilu was exhumed as a crucial spiritual event articulating history, in this article we want to link the explicit importance of Mama Mwuilu (and of women in general) with the equally more and more explicit notions of return to N'kamba-New Jerusalem. Such return is in sharp contrast to other churches or migrants, for whom return is a negligible category. In these cases, 'return' can be a problematic, often conservative assumption on the researchers' side, as has been pointed out by Gerrie Ter Haar ${ }^{7}$. Among Kimbanguists, however, idioms about returning to Africa, often immersed with notions of hope, have now become part-and-parcel of their everyday religiosity. Two of the oldest male Kimbanguists in Lisbon have very recently left Portugal, after almost 30 years of presence there, to resettle themselves in their native Angola, even if they have not secured a job there. This ideology of return should not be taken as a failure of European countries to 'integrate' the Kimbanguists; in fact in Portugal they are well 'integrated' and politically recognized and have managed to construct a home for themselves, a legitimate aspiration for any church settling from abroad. ${ }^{8}$

We start with the bridge, the moment when Kimbanguists in Portugal had their houses and praying place demolished owing to the construction of a bridge over the Tagus. We then move to the moment when the Kimbanguists acquired their temple, to the times when they were contracted by the state and celebrated Christmas in Spring 2009, and to the aspirations of return they have now, analyzed (as our interlocutors often do) in light of the previous events and of Mama Mwilu's second burial in 2009 , as well as in the light of the concept of 'mission,' particularly problematic in this transnational church.

\section{The Bridge}

In the late 1970s and 1980s, when the Kimbanguist church was experiencing difficulties in Angola owing to religious repression, Angolans escaping

\footnotetext{
7) Gerrie Ter Haar, "The African Diaspora in Europe: Some Important Themes and Issues," in: Gerrie ter Haar (ed.), Strangers and Sojourners: Religious Communities in the Diaspora (Leuven: Peeters, 1998), 221-234.

8) Kim Knibbe, “'We did not come here as tenants, but as landlords': Nigerian Pentecostals and the power of maps," African Diaspora 2 (2008), 133-158.
} 
the adverse situation in their country migrated abroad, and many went to the ex-metropolis Lisbon. We do not know exactly how many of them were Kimbanguists, but probably there were only as few as two or three Kimbanguists in Lisbon between 1975 and 1987.

When asked about the origins of their church in Portugal, our interviewees recall a woman, Mama F., a migrant from Angola. Her mother was a devoted Kimbanguist, living in N'kamba-New Jerusalem, close to Diangienda Kuntima (Kimbangu's youngest son), then spiritual leader of the church. Sometime in the late 1970s or early 1980s Mama F. went to N'Kamba-New Jerusalem and took her mother with her to Portugal. They lived together in the neighborhood of Queluz (borough of Sintra), where the mother became a famous healer, consulted by many people. Upon arrival to Portugal, she and her daughter were joined by a Kimbanguist lawyer who had arrived from Luanda. Taking advantage of the fact that the church had already been recognized by the Portuguese state in 1974 in Angola (just one year prior to independence), the Angolan lawyer succeeded in registering the church as a religious institution in Portugal in September 1981. Not much happened, however, for a long time and, apart from the old lady's healing, no religious activity or proselytism was taking place. It was in 1987, with the arrival of Papa Z., that things started to stir.

Papa Z., also an Angolan, went to Lisbon to attend his father's burial. While in Angola, he had heard that there were some Kimbanguists in Portugal, but he failed to meet them for a long time. One night, in a dream, God told him: 'give it up, the thing you are looking for does not exist,' and after that dream he knew that it would be up to him to start a Kimbanguist church in Lisbon and that he had to give up looking for a non-existent one. This said, he did meet the above mentioned Angolan lawyer, sometime in 1989 , but by then the latter was preparing for his return to Angola; meanwhile Mama F.'s mother had passed away. However, Papa Z. met Pastor M., another Kimbanguist who had also migrated to Portugal during the 1980s, followed by his wife and their two children. Together with Mama F., Pastor M. and Papa Z. opened a bank account so as to start organizing the Portuguese Kimbanguist church. Little by little other Kimbanguists arrived from Angola or Congo and joined the prayer group. By the early 1990s, the small Kimbanguist group had developed into a solid network for migrants coming from Angola or Southern Congo, and eventually they gathered enough money to build a small dwelling in Prior Velho, a shanty town in the Municipality of Loures. For many years, 
many Kimbanguists were living in Prior Velho, using the dwelling both as shelter and as a praying space.

Our interviewees recall 'Prior Velho' as a harsh time, full of economic difficulties, all sharing a cramped space. Yet, by no means do they depreciate these days. One of the women we interviewed told us about the satisfaction produced back in those early days by the arrival of more believers and by the realization that a proper church, with its different characteristically Kimbanguist sections (the youths wing, the choirs, the brass band, etc.) was coming into being. As more and more people were coming and joining in on the religious and social ceremonies, the place where the meetings and the co-habitation took place started to resemble a real church: "They even painted the walls in green and white, so that there was no doubt that there were moments where we were on sacred ground," our female interviewee said.

The days in Prior Velho in the late 1980s and 1990s remain in the memory of pioneering Kimbanguists as a time when a community of believers gradually developed. Overall, those days are remembered as the reign of kintuadi, a Kikongo concept our interlocutors usually translate as 'community,' although communitas, in the sense given to this notion by anthropologists since the works of Victor Turner, would probably be a better translation. ${ }^{9}$ They usually recall it as a time in which they all were living together, praying together and living in such poor and marginal conditions that it reminded them of the origins of Christianity in Palestine or of Kimbanguism in rural Africa. ${ }^{10}$

During the 1990s the church established and maintained contact with institutional actors such as the Office for Specific Religious and Social Affairs of Loures. As we could verify in the archives of the Office, Kimbanguists had been sending invitations to government representatives to attend religious celebrations since 1993. This communication turned out to be a good strategy in their immediate future, as we will see.

\footnotetext{
9) Victor Turner, "Passages, Margins and Poverty: Religious Symbols of Communitas," Worship 46/7 (1972), 390-412 \& 46/8 (1972), 482-494.

10) Pastor M. converted from Catholicism to Kimbanguism in Angola. One of the first things that called his attention when joining the Kimbanguist church in rural Angola was the simplicity of their temple, a mere hut in the village, in sharp contrast to the opulent buildings of the Catholic mission. He interpreted that Kimbanguism was more faithful to the roots of Christianity than Catholicism; he often brings this in conversations about the marginal position of migrants in Europe and the role his church has in helping them.
} 
In the mid-1990s, the place where the church and many of its members lived in Prior Velho was declared an area of public interest because of the major international event 'Expo '98' that was to take place in Lisbon in 1998. Because of this international fair, the construction of the monumental twelve-kilometer long bridge, called after Vasco da Gama, was planned over the river Tagus. On its westbound shore, the bridge was to be built on the spot occupied by most of the poorest houses of Prior Velho.

The construction of the Vasco da Gama bridge is remembered with mixed feelings by Loures' immigrant population. On the one hand many men obtained jobs as construction workers, but on the other hand the bridge seems not to have delivered the promises with which it was enthusiastically announced in the 1980s. In 2009, we had the opportunity, together with some Kimbanguists and some Guineans who had worked on its construction, to attend a small exhibition of photographs (organized by the Council of Loures) about the bridge which included, in its inauguration, a public act of thanking the immigrant population who had helped building it. It was shocking for us to realize that the men who had helped build the bridge in 1998 were, in 2009, all unemployed. It was even more shocking to see that no mention had been made to the migrant workers who had died during the building of the bridge, despite it being a fact that remains in the memories of the migrants. For many Portuguese, the Vasco da Gama bridge in the 1990s was a powerful symbol of connection to Europe. For many migrants, and especially for those who, like the Kimbanguists, lost their houses in the process, the bridge comes to their mind with plenty of ambiguities; where invoked in conversations or sermons, it is often used as a symbol of disconnection rather than of connection.

\section{The Temple}

When the shanty towns at Prior Velho had to be dismantled, many of their residents benefited from a Rehousing Programme of the Loures City Council. The process was however very long, and, for our purposes, it meant the scattering of Kimbanguist believers, who, for many years, had nowhere to pray and many of them nowhere to live either. They were dispersed into several households of Greater Lisbon, not living together any longer.

During these years they were helped out by a Catholic priest who let them conduct their religious activities in a center for literacy belonging to the Catholic church. In contrast to the prior time spent in Prior Velho, this 
period is recalled by our interviewees as a time of suffering. One of the women, when recalling it one day after the Sunday service while touching the temple's wall, remarked:

It was a room that belonged to the Catholic church (...) It was not ours. I had no intimacy with the room; it was ours only for a couple of hours. Here we have our colors, Simon Kimbangu's photograph, the green and white, the colors of our church (...) the path of God is never an easy one, we must learn to do what he commands and cope with his will.

Other interviewees also stressed this sense of insecurity and loss, when the community did no longer have a place that they could feel their own, where they were able to fully express their faith as a true community of believers.

As a result of the rehousing program, many of the Kimbanguists and their families where given homes in Quinta da Fonte, a housing project situated in Loures in which an estimated $82 \%$ of the population is made up of African immigrants, and the rest are mostly Ciganos. ${ }^{11}$ It is composed of 554 homes spread over 54 lots. Of these homes, 503 were assigned within the rehousing program. The resettlement of the population occurred between 1996 and 1998. Very astutely, the Kimbanguists soon realized that some buildings in Quinta da Fonte possessed big spaces in their ground floors that were not being used. They saw the opportunity to get their own place of worship, and today still thank God for providing such a circumstance. Because they were a rather well-known religious community to the staff of the Bureau of Religious and Specific Social Affairs of the Loures City Council, with whom they had excellent rapport since their Prior Velho's days, exchanges between them pursued naturally. In one of the letters addressed to the Bureau in 1999, one of the pastors wrote: "Initially the church's headquarters where religious ceremonies were carried out was located in Prior Velho. The demolition of the dwellings in Prior Velho and the rehousing program led to the dispersion of the church's members (desmembramento) and community, which is seeking to reorganize itself." 12

\footnotetext{
11) Ciganos is the Portuguese name for the people often referred to as 'Gypsies' in English; the ethnonym 'Cigano' however, does not have the pejorative tone of the English 'Gypsy' and Ciganos themselves use it proudly.

12) Letter of the National Pastor of the Kimbanguist church to Loures City Council, 30 March 1999. Internal Archives Bureau of Religious and Specific Social Affairs of the Loures City Council (Our translation from Portuguese).
} 
This message of social dissemination and need to reorganize the community, which evokes the previous kintuadi-like lifestyle experienced in Prior Velho as well as the sense of anomie produced by the traumatic demolition of the houses, was successful. The officers at Loures became worried about the lack of a place for this religious community and, much against their own secularist rules, told the Kimbanguists they could use one of the empty spaces of the ground floors for their social gatherings (note that they did not let them have a 'temple,' but rather a center for social gathering and activities, although the Kimbanguists regard it today as their holy temple). On 5 January 2001 a lease agreement between Kimbanguist leaders in Portugal and municipality officials was signed.

Thus, the Kimbanguist community in Portugal, after years of not having an official and stable temple, managed to obtain a free place to worship and express their faith, where men, women and children could head every weekend to celebrate their religious belief. In doing so, they became a privileged church in two fronts: in the first place in comparison with other African groups in Portugal, who normally lack their own space (unless of course they belong to a historical denominational church, such as the Catholic, Methodist, Presbyterian, etc.); in the second place, in comparison with Kimbanguist groups in other European countries. Indeed, despite being bigger and older than the Portuguese group, they lack their own space and are obliged to pay monthly rents for a place to worship. For Kimbanguists, who spend many hours a week in the church (either praying, rehearsing music or in religious and social meetings), having their own place is fundamental, and it is no surprise that the group in Lisbon, despite its minuscule size, is seen as the 'example' to follow by its European sister parishes.

\section{The Contract}

Between 2000 and 2008 Kimbanguists kept a relatively low profile, little by little reconstructing the kintuadi of their previous decade and slowly incorporating new waves of Congolese and Angolese migrants. Things changed again in July 2008, when Quinta da Fonte became an issue on the Portuguese media owing to a violent race-and-drug related conflict within the neighborhood, in particular between Afro-descendants and Cigano inhabitants. The events were so violent that the police had to surround the area during several days, a roundup that obtained huge public attention. It was within this atmosphere that the Kimbanguists, despite being a small 
community mostly unknown to Portuguese until then, started to gain visibility, especially because of their active role in mediating the conflict and in organizing a major peace march in the neighborhood. The march would not have been very visible in itself were it not because of the Kimbanguist fanfare, which creates a difficult-to-miss soundscape and a very impressive visual feast.

The violent events and the peaceful counteraction of the Kimbanguists could not have been timelier. Indeed, at the very time these events were occurring the Portuguese state was planning to start a pilot program in Loures called 'Local Security Contract' (henceforth the Contract). The Contract consisted of a diversity of agreements and partnerships between different social actors: local councils, schools, police, Christian parishes, Muslim associations and some other local associations. Working at different levels, these different agents would cooperate towards the prevention of social manifestations of violence and towards dialogue and peace within the selected area (three freguesias, or local councils, of Loures, one of them being Apelação, where Quinta da Fonte is located). It was intended as a project that should enable a much more sustained and fruitful intervention in 'problematic' and stigmatized residential areas in Portugal. The project received some criticisms. Some local agents told us, for instance, that no effort was being made to reach the really problematic youngsters living in the neighborhood, who do not go to school or belong to any church or association. We lack the capability to make a judgment about the intents or the outcomes of the Contract. But we can say, based on our closeness with many Kimbanguists, that they see it as a blessing.

It was partly owing to the mediating role of the Kimbanguists in the violent encounters between Africans and Ciganos that the Kimbanguist church was invited to be a partner in the Contract. The official ceremony occurred on 12 September 2008, to be renewed annually: the first renewal was celebrated on 7 March 2009 (including 27 partners from the three 'problematic' freguesias). The second renewal (with 13 new partners) took place on 27 March 2010.

The main aim of the contract was, as a Municipality official told us, to strengthen security by focusing on the struggle against domestic violence and youth crime, thus reducing the feeling of insecurity. In order to be a partner of the contract, actors had to propose one or several social activities within their competence and to align these activities within the broad objectives of the Contract. Ultimately, the Contract intended to "create a sense of inclusion, of belonging and of closeness to the place where these 
people live, based on the principle that this is everybody's responsibility", as one of its explicit objectives states. ${ }^{13}$ As far as the Kimbanguist church was concerned, authorities in Loures told us they valued their participation because "since the beginning the Kimbanguist church has shown interest in maintaining well-being within the neighborhood." Before joining the Contract however, Lisbon Kimbanguists had to request permission to the headquarters in N'Kamba-New Jerusalem, which they obtained.

Like all other partners, Kimbanguist were expected to organize activities oriented to the creation of a peaceful atmosphere in the neighborhoods. Among other events, they told the authorities they would like to organize a big Christmas celebration on 25 May 2009. According to the Kimbanguists, Jesus' birth did not take place on 25 December, but rather on 25 May, which is the birthday of Salomon Dialungana Kiangani, Kimbangu's second son, who is identified with Jesus Christ in Kimbanguist theology.

The Government accepted the proposal and allowed the Kimbanguists to celebrate Christmas on the 25 May 2009. It even promised it would secure logistical (and to a small degree, financial) help for the organization. The Christmas celebration happened in a huge sport facility in Loures town on 24 and $25 \mathrm{May}$, and it gathered more than 2,000 Kimbanguists from all over Europe (some accounts even state more than 4,000). Two days before, on Saturday, the $23^{\text {rd }}$, the entire Kimbanguist community celebrated an enormous fanfare march in Lisbon, which started in the central Praça do Rossio and ended in Praça do Comércio, by the river Tagus. On 23 May 2009, downtown Lisbon witnessed a parade consisting of not only members of the Kimbanguist church in Portugal but also worshipers from fellow European countries (France, Belgium, the Netherlands, Switzerland, the United Kingdom and Spain) and Africa (Angola and The Democratic Republic of Congo). The intent of this parade was to show themselves to the Portuguese society, by spreading the 'word of God and the truth of Simon Kimbangu.'

Despite expectations and plans, Simon Kimbangu Kiangani, the Spiritual Leader of the church, did not visit Portugal during the event. However, his classificatory sister, Marie Mwilu Diangienda (daughter of Diangienda Kuntima), came from France in order to represent him. Some

\footnotetext{
13) For a description and objectives of the contract, see http://www.cm-loures.pt/p_lm36D .asp (retrieved 13 July 2011; our translation from the Portuguese).
} 
people were disappointed not to meet Simon Kimbangu in Lisbon, but, as the national pastor told us: "it is the same thing, whether it is Kimbangu or his sister, they are both the same." This feminization of the event should not be unnoticed, and in our opinion should be interpreted in the wider feminization of the church we already signaled. It was particularly meaningful if we took into account that it was happening the same year of the jubilee of Mama Mwilu and only a few months before her "Triumphal Entry" into the family mausoleum, which represents the re-balancing and reunification of cosmic forces. It is quite frequent to hear "Mama Mwilu has entered [...], now things are going to change" suggesting that now that the whole family is reunited, they are all working together for the community, conjointly listening to the worshipers' prayers. Mama Mwilu's Triumphal Entry and the family reunification are also important aspects to take into consideration to understand the will of the 'return to Africa' discussed at the end of this article. ${ }^{14}$ The feminization was also quite significant if we took into account that today in many Kimbanguist homes in Europe it is women who secure the household's economy (in one European parish, that of Liege, in Belgium, it is a woman who is the main pastor of the community).

The next day, during the sermon, this was recalled as a breaking point. Kimbanguists had jumped from total obscurity to be leading a massive march in Lisbon's historical centre. "Nothing will be the same," said the pastor. He continued by asserting that "many Portuguese were thinking about what we said [yesterday].” Indeed it was a very successful event, with thousands of Kimbanguists from all over Europe coming to celebrate Christmas in Lisbon, and the Kimbanguists got an even bigger presence in Portuguese social space. Furthermore, because of the big success in the preparation, they embellished their image vis-à-vis the other European parishes (France, Belgium, the UK, etc.), which now see Lisbon as the example to follow.

On 25 May, during the worship of Christmas day, Marie Mwilu Diangienda solemnly announced, in the name of Simon Kimbangu Kiangani, two new dogmas of the church: firstly, that Salomon Dialungana Kiangani (Simon Kimbangu's second son and father of Simon Kimbangu

\footnotetext{
14) According to Kimbanguist interpretations, the re-balancing of spiritual and cosmic forces brought about by Mama Mwilu's reunion with her husband implies more responsibility upon individuals. They must build and maintain balance and unity within their communities, their families, and within themselves.
} 
Kiangani) is Jesus Christ born in Africa. Secondly, that Our Lady of Fatima (who, many Catholics believe, appeared to three small children in Portugal in 1917 and who is the biggest symbol of Portuguese Catholicism) was in fact Mama Mwilu (Kimbangu's wife), who had appeared in Europe to let people know that Jesus Christ had just been born in Africa on 25 May 1916 (Dialungana’s birth day).

According to many Kimbanguists, the collaboration of the Kimbanguist church in the Contract constitutes the recognition by the Portuguese state of the positive contribution that the church provides within the neighborhood. It also implies, from the Kimbanguists point of view, the recognition of the importance that religion and its moral canons have when it comes to conveying social cohesion. It reinforces their feeling that Europe has gone wrong when trying to dissipate it from the public sphere, and it is up to them to bring it back where it belongs.

\section{Mission and Return}

As has been argued elsewhere Kimbanguism lives in a fragile ebb-and-flow equilibrium between its center and periphery. ${ }^{15}$ There is a tension between centrifugal forces that tend to expand the community and disseminate it through notions and practices of diaspora, conversion and universality, and centripetal forces that tend to collapse it towards Africa (in particular towards N'kamba-New Jerusalem) and toward notions of ethnic exclusiveness or, at least of divine election. As one pastor told us: "From time to time, God chooses one people: in the past He chose the Hebrews, but now He has chosen the Kimbanguists."

These tensions are important when analyzing notions of 'mission.' Kimbanguists could be described as having a missionary ethos. Some of their discourses (as in sermons or general conversations) do fit in the general model of 'reverse mission'; like many Christians coming from nonWestern contexts, they see Europe as a secularized space in which people have forgotten God, and their role as that of bringing Him back into this

\footnotetext{
15) Ramon Sarró \& Anne Mélice, "Kongo and Lisbon: The Dialectics of 'Centre' and 'Periphery' in the Kimbanguist Church," in: Sandra Fancello \& André Mary (eds.), Chrétiens Africains en Europe: Prophétismes, Pentecôtismes et Politique des Nations (Paris: Karthala 2010), 43-67.
} 
spiritually hollow space. ${ }^{16}$ "Little did the European expect that their younger brother would bring God back to them," a pastor once told us. The same pastor some years later told us that Kimbanguism has not one, but three missions. The first one is spiritual: through the belief in Simon Kimbangu many souls can be saved. The second is political; in his words "we all need to know that before Simon Kimbangu there was no true African Christian church and it is necessary that there be no submission and domination of some over the others, this is not the path towards harmony." The third goal he mentioned was scientific, because "it has been for too long now that the West has despised African knowledge and science, but in Africa we also have knowledge and we must affirm it."

Yet, despite a general use of the concept of 'mission' to refer to the church's main goals for humanity, as was the case in this and other conversations, when discussing notions of 'mission' among Kimbanguists we have to take two things into account. Firstly, very often our interviewees have told us that they feel a bit put off by the notion of 'mission' because of its colonial connotations. 'Mission' means, according to some of them at any rate, the imposition of a religion onto a people who had another one. They prefer to talk about 'evangelization,' which they define as a process in which the truth is unveiled rather than imposed.

Secondly, even if we accepted the concept of mission as an analytical tool to describe the desire of Kimbanguists to expand their community or their strategies to do so, we would have to agree that there is no pro-active or explicit missionary attitude among Kimbanguists. One of the pastors in Lisbon usually reminds us of the dictum "good wine needs no bush," a phrase he normally uses to criticize pastors of some Christian churches whose proselytizing is active and can be annoying. The Kimbanguists' attitude is one of example, of being good neighbors, of relying in God's providence (as proved in giving them a temple in Quinta da Fonte, or making them a partner of the Contract). And, especially, of being good with non-Kimbanguist people, with the hope, avowed to us in several occasions, that they will see that the truth of Kimbanguist religion and convert into it.

16) Afe Adogame, "Globalization and African New Religious Movements in Europe," in: Ogbu U. Kalu \& Alaine Low (eds.), Interpreting Contemporary Christianity: Global Processes and Local Identities (Grand Rapids: William B. Eerdmans Publishing, 2008), 296-316; Israel Olofinjana, Reverse in Ministry and Missions: Africans in the Dark Continent of Europe (Milton Keynes: AuthorHouse, 2010). 
Kimbanguists in Lisbon are always willing to pray at someone's home, whether or not this person is a Kimbanguist. Some years ago, for instance, they were visited by a man who was living far away from the church's headquarters, but who had heard about the group prayers organized by this religious community. Apparently, his wife did not want to leave the house under any circumstance, not even to go to the corner shop. At the man's request, some Kimbanguists headed to their home and prayed for the woman, on several occasions. After some time the woman started to go outside her place and finally even dared going by car to the supermarket. The Kimbanguists treated the woman as a suffering fellow, not a medical patient. Therefore, they did what they usually do to a suffering fellow in order to appease the tormented spirit: they prayed. After her recovery, the woman went to the Kimbanguist church to express her gratitude, although she did not convert to their religion. We have witnessed other cases in which people who have been spiritually helped by the Kimbanguists have come to the church to express gratitude but have not become adepts. This disappoints the Kimbanguists, but does not deter them from continuing to help their neighbors. And vice versa, the fact that they are not pressuring anybody to convert and that they work on a stoic good-wine-needs-nobush philosophy reinforces their spiritual presence and makes people trust them and their services.

In providing this spiritual support, men and women must work together. Prayers in peoples' houses can be done by men, women or both. But even if it is only men, our interviewees tell us, women have to support them and give them instructions. There is a high emphasis on the dual element, implying that reciprocity and mutualism between genders provide a balanced experience of life, community and well-being. ${ }^{17}$ According to our interviewees women are conceived as possessing a maternal and sensible character, and it is this aspect of the feminine condition that endows women's requests and prayers with a greater ability to monitor spiritual and transcendent forces. One of the women we interviewed, while explaining the importance of the Association of Kimbanguist Women, ended up stating that "men may always be leading, but women are their counselors, because we, women, are, maybe by nature, more sensitive. Even our Papa Diangienda Kuntima [Kimbangu's son], used to say that papas and mamas

17) If Amadiume, Reinventing Africa: Matriarchy, Religion and Culture (London \& New York: Zed Books Ltd., 1997). 
may be praying side by side, but a mama's prayer will always arrive first, because it is just the way it is; it is God's will."

Some of the women we have interviewed express an ambivalence towards the strictures of 'example' as put forth mostly by our male interlocutors, and some have expressed that they would like their mission to be more explicit. One of the young women we interviewed, despite not showing her religious identity as explicitly as the older ones do (she only admits her religion in very specific moments and if necessary, such as when she goes out with friends and has to explain why she is not drinking or smoking) asserted that:

[the mission] is quite important, because in the end, they'll ask you: to whom did you speak to? They say during sermons that at the end we are the ones who shall be stoned, because when people realize the grandiosity of this message they will revolt against us because we never told them, we kept it for ourselves.

This phrase encapsulates the internal tensions between implicit and explicit missionary attitudes. One could, for instance, interpret some female strategies, in particular their wearing garments with a myriad of explicit references to the church (their clothes contain images of Kimbangu, of N'Kamba-New Jerusalem, of Mama Mwilu, of Diangienda Kuntima, etc.) as one way to embody the example and to make an explicit point as to who they are and to which church they belong, should anyone be interested in following them.

The notion of setting an example and of good behavior has to be analyzed in conjunction with another important element of mission (of any mission): success. What would a successful mission be? For Kimbanguists the success of their mission in Portugal would be to convert a Portuguese man or woman to Kimbanguism. Not only because that would validate the universality of their religion, always questioned (in Angola sometimes people refer to Kimbanguism with the derogatory term of Bakongada, i.e, something limited to the Bakongo people), but also because it would finally mean, so to speak, the end of the 'mission' too. From that moment onwards, Kimbanguism would not be a foreign religion in Portugal, but an autochthonous one-to use the concept some of our interlocutors have used. The person thus converted could be, if the ecclesiastic authorities in N'Kamba-New Jerusalem agreed, nominated 'National Representative' of the church in Portugal. This title cannot be given to a foreigner and, so far, 
only exists in some African countries but not in Europe, since Kimbanguists have so far failed to convert Europeans into their faith and thus to make it an autochthonous church in Europe.

Many of our interviewees link the notion of success to the notion of return, it being a notion that emerges very often in our conversations among Kimbanguists. Owing to the critical economic situation in Portugal today and to the fact that many Kimbanguists are unemployed (more men than women, in fact), it should not surprise us that, like many other Angolans in Portugal, they are thinking of going back to their post-war country. Yet, among Kimbanguists 'return' is more a theological category than an intention or a life project. Return is where the believers' minds should be oriented towards. It is not only that as poor migrants they might want to go back to a better condition, or that, as human beings, they might have a nostalgic relationship with their place of origin. It is all that, but also that the church is more and more oriented towards generating discourses, and even mandates, of return to Africa that have to do with eschatological and apocalyptic notions about the layisua, the end of history. When layisua arrives, the entire world will fall asleep but only the good people will awake and live in a peaceful eternity (some interviewees have told me that only the Kimbanguists will awake). It is very important for Kimbanguists that the layisua should find them in Nkamba-New Jurusalem.

A Kikongo proverb has it that "when you see bits of chewed sugarcane on the path you're walking, it means you are approaching a market place." Many of the things that we are witnessing today, from Obama's election to the economic crisis in Europe (and of course the exhumation of Mama Mwilu) are bits of chewed sugarcane, signs indicating that the layisua as the Kimbanguists understand it is approaching. In the late 1990s, the leader of the Kimbanguist church, Salomon Dialungana, Simon Kimbangu's third son, ordered the building of Nkendelo (literally meaning, in Kikongo, "the limit"), a hamlet in N'kamba-New Jersualem. In this place, 326 houses are to be built so as to house the black Americans who will return to Africa, according to Kimbanguist prophecies. Today Nkendelo is still in the building, and the amount of money that people leave (and send) every Sunday in church for its construction is quite substantial. Kimbanguists are sure not only that old-diasporical Black Americans will return to Africa where they belong, but also that Africans living in Europe must return. "Prepare yourself to go back" is now an admonition of the church. And if the Kimbanguist church has succeeded in anything, it is in 
producing a sense of pride of being African that cuts across genders and generations. Even second generation Kimbanguists, those born in Portugal and whose identity is clearly more hybrid than their parents', express a pride of being African and, many of them, developing a project to go ('back') to the African continent.

\section{Conclusion}

An ideology of return is nowadays emerging among our Kimbanguist interlocutors, linked to the notion that Satan has been finally expelled from this world. Kimbanguists claim that they are getting ready to go back to Africa and to live in N'kamba-New Jerusalem, where the layisua must find them. The events of 12 October 2009, with the Triumphal Entry of Mama Mwilu in N'kamba-New Jerusalem and the final reunion of Simon Kimbangu with his wife, have established that "this is the moment." Many are indeed preparing themselves, spiritually and economically, for this return, although the exact nature of the time of return is difficult to grasp, and often sounds more like an eschatological than a historical project. For Kimbanguists of Portugal, at any rate, the exhumation of Mama Mwuilu and her reunion with Kimbangu is the extraordinary moment that reveals the hidden sense of the events experienced so far and that indicates that the future promised by Kimbangu is now approaching. 